\title{
Precipitable silver compound catalysts for the selective catalytic reduction of NOx by ethanol
}

\author{
Hong $\mathrm{He}^{*}$, Yi Li, Xiuli Zhang, Yunbo Yu, Changbin Zhang \\ State Key Laboratory of Environmental Chemistry and Ecotoxicology, Research Center for Eco-Environmental Sciences, Chinese Academy of Sciences, P.O. Box 2871, \\ 18 Shuangqing Road, Haidian District, Beijing 100085, PR China
}

\section{A R T I C L E I N F O}

\section{Article history:}

Received 3 June 2009

Received in revised form 23 December 2009

Accepted 6 January 2010

Available online 11 January 2010

\section{Keywords:}

NOx

Selective catalytic reduction

Ag species

Silver compound catalysts

Precipitator

\begin{abstract}
A B S T R A C T
The $\mathrm{Ag} / \mathrm{Al}_{2} \mathrm{O}_{3}, \mathrm{Ag}_{3} \mathrm{PO}_{4} / \mathrm{Al}_{2} \mathrm{O}_{3}, \mathrm{Ag}_{2} \mathrm{SO}_{4} / \mathrm{Al}_{2} \mathrm{O}_{3}$ and $\mathrm{AgCl} / \mathrm{Al}_{2} \mathrm{O}_{3}$ catalysts showed high activities for the selective catalytic reduction (SCR) of NOx by ethanol. $\mathrm{AgCl}$ was highly crystalloid on $\mathrm{Al}_{2} \mathrm{O}_{3}$, however, $\mathrm{AgCl} / \mathrm{Al}_{2} \mathrm{O}_{3}$ gave the highest catalytic turnover frequency (TOF) for NOx reduction among the four catalysts. Calculated Mulliken charges of Ag compounds support the TOF results. The activity test and characterization results confirm that $\mathrm{Ag}^{+}$is the active silver species for NOx reduction. The in situ FT-IR results of $\mathrm{Ag}_{3} \mathrm{PO}_{4} / \mathrm{Al}_{2} \mathrm{O}_{3}, \mathrm{Ag}_{2} \mathrm{SO}_{4} / \mathrm{Al}_{2} \mathrm{O}_{3}$ and $\mathrm{AgCl} / \mathrm{Al}_{2} \mathrm{O}_{3}$ for NOx reduction further reveal a positive correlation between the high dispersion of $\mathrm{Ag}^{+}$and the formation of active intermediates (the enolic and -NCO species), indicating a similar reaction pathway to that of the ethanol-SCR over $\mathrm{Ag} / \mathrm{Al}_{2} \mathrm{O}_{3}$. Using the precipitable silver compounds greatly facilitates the preparation of monolith $\mathrm{Ag} / \mathrm{Al}_{2} \mathrm{O}_{3}$ catalyst for practical usage. In fact, the high performance of the $\mathrm{AgCl} / \mathrm{Al}_{2} \mathrm{O}_{3}$ honeycomb catalyst was confirmed by heavy duty diesel engine bench tests.
\end{abstract}

(c) 2010 Elsevier B.V. All rights reserved.

\section{Introduction}

The selective catalytic reduction of NOx by hydrocarbons (HC$\mathrm{SCR}$ ) is a potential method to remove NOx from oxygen rich exhausts of automobiles and stationary facilities. $\mathrm{Ag} / \mathrm{Al}_{2} \mathrm{O}_{3}$ is known to be one of the most effective catalysts for the SCR of NOx by hydrocarbons. So far, catalytic performance, catalyst characterization and reaction mechanism of the HC-SCR of NOx over Ag/ $\mathrm{Al}_{2} \mathrm{O}_{3}$ have been investigated in detail by many researchers, as well as applications on the de-NOx of diesel engine exhaust [1-15]. Since the catalytic performance of $\mathrm{Ag} / \mathrm{Al}_{2} \mathrm{O}_{3}$ has a close relationship with $\mathrm{Ag}$ loading and the $\mathrm{Ag}$ physical and chemical states, the structures of the $\mathrm{Ag}$ species as active sites on $\mathrm{Al}_{2} \mathrm{O}_{3}$ have attracted much attention $[4,9,11,16,17]$. It is accepted that silver oxide species with high dispersion are observed with lower Ag loading, and their presence is related to their high NOx reduction performance $[2,9,16,18,19]$. On the contrary, a higher percentage of metal loading correlates with the formation of metallic Ag on the catalyst surface, which favors oxidation of the reductant by $\mathrm{O}_{2}$ and decreases its selectivity for NOx reduction $[4,9,16,19]$. Usually, the highest HC-SCR activity can be observed at low or moderate Ag loadings (2-4 wt.\%). Miyadera [2] proposed that oxidized Ag

\footnotetext{
* Corresponding author. Tel.: +8610 62849123; fax: +861062849123.

E-mail address: honghe@rcees.ac.cn (H. He).
}

species interacting with the alumina support were the active phase for the HC-SCR reactions. Hoost et al. [10] pointed out that metalsupport interaction might be associated with high de-NOx efficiency on the optimum $2 \mathrm{wt} . \% \mathrm{Ag} / \mathrm{Al}_{2} \mathrm{O}_{3}$. Bethke and Kung [4] reported that 2 wt.\% $\mathrm{Ag} / \mathrm{Al}_{2} \mathrm{O}_{3}$ contained $\mathrm{Ag}$ in the +1 oxidation state, which resulted in a high NOx conversion, while the $6 \mathrm{wt} . \%$ $\mathrm{Ag} / \mathrm{Al}_{2} \mathrm{O}_{3}$ contained $\mathrm{Ag}^{0}$ particles, which resulted in a high rate of $\mathrm{C}_{3} \mathrm{H}_{6}$ combustion at the expense of NOx reduction. Shimizu et al. [9] have reported that highly dispersed $\mathrm{Ag}^{+}$ions are the dominant $\mathrm{Ag}$ species in the case of $2 \mathrm{wt} . \% \mathrm{Ag}$ loading or below, and are responsible for the selective reduction of $\mathrm{NO}$ to $\mathrm{N}_{2}$ over $\mathrm{Ag} / \mathrm{Al}_{2} \mathrm{O}_{3}$ by higher hydrocarbons. These reports strongly suggest that the oxidation state of $\mathrm{Ag}$ on $\mathrm{Ag} / \mathrm{Al}_{2} \mathrm{O}_{3}$ catalyst is very important for the de-NOx performance, even though the active $\mathrm{Ag}$ phase might have different structures, such as isolated $\mathrm{Ag}^{+}$ions, $\mathrm{Ag}_{n}{ }^{\delta+}$ clusters, silver oxide and silver aluminate.

Various methods have been used to obtain a catalyst containing the +1 state of $\mathrm{Ag}$, including choosing different preparation methods and supports. It is known that impregnation of the alumina supports with a silver salt solution can lead to a wide distribution of $\mathrm{Ag}$ species according to the loading and kind of alumina used. The sol-gel [9,20], multiple impregnation [10], coprecipitation [20] and inverse micro-emulsion [21] methods were used to prepare the catalysts to obtain a greater dispersion of the metal cations or to promote strong interactions with the alumina support. Dilute nitric acid leaching has been used to remove $\mathrm{Ag}$ 
particles and all weakly bound $\mathrm{Ag}$ from the surface of $\mathrm{Ag} / \mathrm{Al}_{2} \mathrm{O}_{3}$ [22].

In the previous studies $[2,6,23]$, ethanol was shown to be extremely effective for $\mathrm{NOx}$ reduction over $\mathrm{Ag} / \mathrm{Al}_{2} \mathrm{O}_{3}$ in the presence of $\mathrm{H}_{2} \mathrm{O}$ and $\mathrm{SO}_{2}$. As for the reaction mechanism of the SCR of NOx by ethanol, we have attributed the excellent performance for the SCR of NOx by ethanol to the formation of enolic species on $\mathrm{Ag} / \mathrm{Al}_{2} \mathrm{O}_{3}[24,25]$. The adsorbed enolic species is more active to react with $\mathrm{NO}+\mathrm{O}_{2}$ on $\mathrm{Ag} / \mathrm{Al}_{2} \mathrm{O}_{3}$ than acetate, and plays a crucial role in the formation of $-\mathrm{NCO}$ which is a key intermediate during the SCR of NOx. However, the relationship between the active $\mathrm{Ag}$ site structure and the SCR activity has not been reported in detail. Moreover, eluted $\mathrm{Ag}^{+}$ions from $\mathrm{Ag} / \mathrm{Al}_{2} \mathrm{O}_{3}$ were found in the water [26]. The release of the $\mathrm{Ag}^{+}$ions resulted in a re-distribution of $\mathrm{Ag}$ species during the preparation of $\mathrm{Ag} / \mathrm{Al}_{2} \mathrm{O}_{3}$ washcoated cordierite honeycomb catalysts, further influencing the stability of the catalysts for NOx reduction. In fact, precipitable silver compounds can be used to stabilize and control the state of the Ag phase. However, little research involving this aspect has been conducted [11,27-29].

The aim of the present work is to investigate the fixation and stabilization of $\mathrm{Ag}$ species on $\mathrm{Al}_{2} \mathrm{O}_{3}$, and to develop a better understanding of the active nature of $\mathrm{Ag} / \mathrm{Al}_{2} \mathrm{O}_{3}$ for $\mathrm{NOx}$ reduction by ethanol. For this purpose, $\mathrm{AgNO}_{3}$ was used as the $\mathrm{Ag}$ precursor, while $\left(\mathrm{NH}_{4}\right)_{3} \mathrm{PO}_{4},\left(\mathrm{NH}_{4}\right)_{2} \mathrm{SO}_{4}$ and $\mathrm{NH}_{4} \mathrm{Cl}$ were used to precipitate silver compounds on $\mathrm{Al}_{2} \mathrm{O}_{3}$. The catalysts were characterized by $\mathrm{N}_{2}$ adsorption, X-ray diffraction (XRD) and X-ray photoelectron spectroscopy (XPS) measurements. The dispersion of the $\mathrm{Ag}$ species was measured by $\mathrm{H}_{2}-\mathrm{O}_{2}$ titration, and the turnover frequency (TOF) of NOx conversion was calculated to compare the activities of silver oxide, $\mathrm{AgCl}, \mathrm{Ag}_{3} \mathrm{PO}_{4}$ and $\mathrm{Ag}_{2} \mathrm{SO}_{4}$. The in situ diffuse reflectance infrared Fourier transform spectroscopy (DRIFTS) was used to investigate the intermediates interacting with the active Ag sites during NOx reduction.

\section{Experimental}

\subsection{Catalyst preparation}

\subsubsection{Preparation of powder catalysts}

The AlOOH powder ( surface area $=292.1 \mathrm{~m}^{2} \mathrm{~g}^{-1}$ ), used as $\mathrm{Al}_{2} \mathrm{O}_{3}$ precursor, was impregnated with an appropriate amount of silver nitrate aqueous solution to obtain a suspension. Subsequently, an appropriate amount of ammonium phosphate, ammonium sulfate or ammonium chloride was added dropwise to the suspension. The suspension was then dried at $393 \mathrm{~K}$ overnight and calcined at $873 \mathrm{~K}$ for $3 \mathrm{~h}$ in air to obtain the $\mathrm{Ag} / \mathrm{Al}_{2} \mathrm{O}_{3}, \mathrm{Ag}_{3} \mathrm{PO}_{4} / \mathrm{Al}_{2} \mathrm{O}_{3}, \mathrm{Ag}_{2} \mathrm{SO}_{4} /$ $\mathrm{Al}_{2} \mathrm{O}_{3}$ or $\mathrm{AgCl} / \mathrm{Al}_{2} \mathrm{O}_{3}$ catalysts. $\mathrm{Ag}_{3} \mathrm{PO}_{4}, \mathrm{Ag}_{2} \mathrm{SO}_{4}$ and $\mathrm{AgCl}$ should not be decomposed at $873 \mathrm{~K}$. In all cases, $\mathrm{Ag}$ loading of these catalysts was 4 wt.\%.

\subsubsection{Preparation of washcoated honeycomb catalysts}

Washcoated honeycomb catalysts were prepared using the $\mathrm{Ag}_{3} \mathrm{PO}_{4} / \mathrm{Al}_{2} \mathrm{O}_{3}$ and $\mathrm{AgCl} / \mathrm{Al}_{2} \mathrm{O}_{3}$ powder catalysts. Washcoat slurries were prepared by mixing $250 \mathrm{~g}$ of powder with $750 \mathrm{~g}$ of water using a ball mill. Cordierite honeycombs with 400 cells per square inch (90 $\mathrm{mm}$ in diameter $\times 110 \mathrm{~mm}$ in length) were dipped into the washcoat slurry, and excess slurry was blown out with an air jet. The samples were then dried at $393 \mathrm{~K}$ overnight and calcined at $873 \mathrm{~K}$ for $3 \mathrm{~h}$. The washcoat loading was $110 \mathrm{~g} \mathrm{~L}^{-1}$ after calcination.

\subsection{Catalyst activity test}

The measurement of the catalytic activity of $\mathrm{Ag} / \mathrm{Al}_{2} \mathrm{O}_{3}, \mathrm{Ag}_{3} \mathrm{PO}_{4} /$ $\mathrm{Al}_{2} \mathrm{O}_{3}, \mathrm{Ag}_{2} \mathrm{SO}_{4} / \mathrm{Al}_{2} \mathrm{O}_{3}$ and $\mathrm{AgCl} / \mathrm{Al}_{2} \mathrm{O}_{3}$ powder catalysts was carried out in a fixed-bed reactor connected with a temperature controller.
The typical experiment conditions were as follows. The feed gas stream consisted of $800 \mathrm{ppm} \mathrm{NO}, 1565 \mathrm{ppm} \mathrm{C} \mathrm{C}_{2} \mathrm{H}_{5} \mathrm{OH}, 10 \% \mathrm{O}_{2}$ and $10 \% \mathrm{H}_{2} \mathrm{O}$ with $\mathrm{N}_{2}$ as the balance. The total gas flow rate was $2000 \mathrm{~cm}^{3} \mathrm{~min}^{-1}$ over $0.6 \mathrm{~g}$ catalyst (about $2.4 \mathrm{ml}$ ). W/ $\mathrm{F}=0.018 \mathrm{~g} \mathrm{~s} \mathrm{~cm}^{-3}$, gas hourly space velocity $(\mathrm{GHSV})=\sim 50,000 \mathrm{~h}^{-1}$. -1 . The NOx conversion was analyzed on-line by a chemiluminescence $\mathrm{NO} / \mathrm{NO}_{2} / \mathrm{NOx}$ analyzer (42C-HL, Thermo Environmental Instruments Inc.). Meanwhile, the concentration of $\mathrm{N}_{2} \mathrm{O}$ during the NOx reduction was measured on-line by an Agilent 6890N GC equipped with a Porapak Q column and a TCD detector (Agilent Technologies). In addition, the formation of organo-nitrogen compounds was also detected by GC-MS (Agilent GC (6890N)-MS (5973N), Agilent Technologies). Thus, $\mathrm{N}_{2}$ concentration was calculated assuming that there was a mass balance of $100 \%$ for all the nitrogen-containing molecules $[8,16,17]$.

The $\mathrm{Ag}_{3} \mathrm{PO}_{4} / \mathrm{Al}_{2} \mathrm{O}_{3}$ and $\mathrm{AgCl} / \mathrm{Al}_{2} \mathrm{O}_{3}$ washcoat honeycomb catalysts were cut into small pieces (about $1.2 \mathrm{~cm}$ in diameter, $2.2 \mathrm{~cm}$ in length, and $2.5 \mathrm{~cm}^{3}$ in volume), and the measurements of the catalytic activity were carried out in the fixed-bed reactor. The feed gas stream consisted of $800 \mathrm{ppm} \mathrm{NO}, 1565 \mathrm{ppm} \mathrm{C}_{2} \mathrm{H}_{5} \mathrm{OH}, 10 \%$ $\mathrm{O}_{2}$ and $10 \% \mathrm{H}_{2} \mathrm{O}$ with $\mathrm{N}_{2}$ as the balance (GHSV $=50,000 \mathrm{~h}^{-1}, \mathrm{~W} /$ $\mathrm{F}=0.008 \mathrm{~g} \mathrm{~s} \mathrm{~cm}^{-3}$ ).

The $\mathrm{AgCl} / \mathrm{Al}_{2} \mathrm{O}_{3}$ washcoated honeycomb catalyst was used in the diesel engine bench tests $\left(\mathrm{GHSV}=\sim 30,000 \mathrm{~h}^{-1}\right)$; the NOx conversion was measured with a gas analyzer (CEB-2, AVL). The engine used in this experiment was a Sofim 8140-43C diesel engine (four-cylinder direct injection, displacement $2.8 \mathrm{~L}$, compression ratio $18.5: 1$, rated power/speed $76 \mathrm{~kW} / 3600 \mathrm{rpm}$ ) as described in the previous work $[30,31]$. A portion of the exhaust gas was extracted and passed through a particulate trap. The catalysts were exposed to the exhaust with $\mathrm{C}_{2} \mathrm{H}_{5} \mathrm{OH}$ injection in front of the catalyst. The tests were conducted under the following conditions: engine speed $3450 \mathrm{rpm}$, torque $195 \mathrm{~N} \mathrm{~m}$ (full load), original NOx emission $6.924 \mathrm{~g} \mathrm{~kW}^{-1} \mathrm{~h}^{-1}$ (around $500 \mathrm{ppm}$ ), $\mathrm{C}_{2} \mathrm{H}_{5} \mathrm{OH} / \mathrm{NOx}=3: 1$ on a mass ratio.

\subsection{Catalyst characterization}

The nitrogen adsorption-desorption isotherms were obtained at $77 \mathrm{~K}$ over the whole range of relative pressures, using a Quantasorb-18 (Quanta Chrome Instrument Co.). Specific areas were computed from these isotherms by applying the BrunauerEmmett-Teller (BET) method.

The samples were characterized by XRD using a computerized Rigaku D/max-RB Diffractometer (Japan, $\mathrm{Cu} K \alpha$ radiation, $0.154056 \mathrm{~nm})$. Scans were taken over a $2 \theta$ range of $10-90^{\circ}$ at a speed of $4^{\circ} \mathrm{min}^{-1}$.

The catalysts were analyzed using XPS to identify the surface nature and concentration of the active species. Spectra were recorded by an ESCALAB Mark II spectrometer (Thermo ESCALAB 250, USA) using $\mathrm{Al} \mathrm{K \alpha}$ radiation ( $h v=1486.6 \mathrm{eV})$.

\subsection{TOF study}

$\mathrm{Ag}$ dispersions for $\mathrm{Ag} / \mathrm{Al}_{2} \mathrm{O}_{3}, \mathrm{Ag}_{3} \mathrm{PO}_{4} / \mathrm{Al}_{2} \mathrm{O}_{3}, \mathrm{Ag}_{2} \mathrm{SO}_{4} / \mathrm{Al}_{2} \mathrm{O}_{3}$ and $\mathrm{AgCl} / \mathrm{Al}_{2} \mathrm{O}_{3}$ were measured using $\mathrm{H}_{2}-\mathrm{O}_{2}$ titration [10], which was performed on a fixed-bed flow reactor system equipped with a computer-interfaced quadruple mass spectrometer (Hiden HPR 20 ). In order to remove the surface contaminants such as water and carbonates species, the catalyst sample was pretreated in $20 \% \mathrm{O}_{2}$ at $773 \mathrm{~K}$ for $30 \mathrm{~min}$. After cooling to room temperature in the same atmosphere, the catalyst was reduced in a flow of $\mathrm{H}_{2} / \mathrm{Ar}(5 \%)$ for $2 \mathrm{~h}$ at $523 \mathrm{~K}$ (raised at a ramp of $10 \mathrm{~K} \mathrm{~min}^{-1}$ ), and cooled to $443 \mathrm{~K}$ (the temperature of $\mathrm{O}_{2}$ adsorption) in the same atmosphere. Then the sample was purged with $30 \mathrm{~cm}^{3} \mathrm{~min}^{-1} \mathrm{He}$ stream for $30 \mathrm{~min}$, and $\mathrm{O}_{2}$ adsorption took place in a flow of $20 \% \mathrm{O}_{2}$ for $90 \mathrm{~min}$ (for $\mathrm{Ag}_{3} \mathrm{PO}_{4} /$ 
$\mathrm{Al}_{2} \mathrm{O}_{3}, \mathrm{Ag}_{2} \mathrm{SO}_{4} / \mathrm{Al}_{2} \mathrm{O}_{3}, \mathrm{AgCl} / \mathrm{Al}_{2} \mathrm{O}_{3}$ ) or $30 \mathrm{~min}$ (for $\mathrm{Ag} / \mathrm{Al}_{2} \mathrm{O}_{3}$ ) at the same temperature $(443 \mathrm{~K})$. After a second purge by $30 \mathrm{~cm}^{3} \mathrm{~min}^{-1}$ $\mathrm{He}$ for $30 \mathrm{~min}$, the adsorbed oxygen was titrated using $\mathrm{H}_{2} / \mathrm{Ar}(5 \%)$, and the amount of hydrogen consumed was determined by a mass spectrometer. We selected the reduction temperature at $523 \mathrm{~K}$ (raised at a ramp of $10 \mathrm{~K} \mathrm{~min}^{-1}$ ) and the reduction pretreatment of $2 \mathrm{~h}$ to ensure that the degree of reduction in these conditions was approximately $100 \%$.

The $\mathrm{Ag}$ dispersion was calculated on the total adsorption stoichiometric ratio of $\mathrm{Ag} / \mathrm{O}_{2}=2$ and $\mathrm{Ag} / \mathrm{H}_{2}=1$ [10]. In this paper, the $\mathrm{Ag}$ dispersion and TOF for the NOx reduction over the $\mathrm{Ag}$ species are expressed using Eqs. (1) and (2):

$\operatorname{Ag}$ dispersion $(\%)=\frac{n_{\mathrm{Ag}(\text { calculation })}(\mathrm{mol})}{n_{\mathrm{Ag}}(\mathrm{mol})} \times 100$

$\operatorname{TOF}\left(\mathrm{s}^{-1}\right)=\frac{\text { NOx conversion }\left(\mathrm{mol} \mathrm{s}^{-1}\right)}{n_{\mathrm{Ag}}(\mathrm{mol}) \times \mathrm{Ag} \text { dispersion }}$

where $n_{\mathrm{Ag} \text { (calculation) }}$ is the calculated mole number of the surface $\mathrm{Ag}$ from $\mathrm{H}_{2}-\mathrm{O}_{2}$ titration, and $n_{\mathrm{Ag}}$ is the total mole number of $4 \mathrm{wt} . \%$ $\mathrm{Ag}$ loaded on the alumina support. Based on the $\mathrm{Ag}$ dispersion and NOx conversion at $523 \mathrm{~K}$, the TOFs for $\mathrm{Ag} / \mathrm{Al}_{2} \mathrm{O}_{3}, \mathrm{Ag}_{3} \mathrm{PO}_{4} / \mathrm{Al}_{2} \mathrm{O}_{3}$, $\mathrm{Ag}_{2} \mathrm{SO}_{4} / \mathrm{Al}_{2} \mathrm{O}_{3}$ and $\mathrm{AgCl} / \mathrm{Al}_{2} \mathrm{O}_{3}$ catalysts were calculated using Eq. (2).

\subsection{In situ DRIFTS study}

In situ DRIFTS experiments were performed on a Nexus 670 (Thermo Nicolet) FT-IR spectrometer equipped with an in situ diffuse reflection chamber and a high-sensitivity $\mathrm{MCT}$ detector. In these studies, the $\mathrm{Ag} / \mathrm{Al}_{2} \mathrm{O}_{3}, \mathrm{Ag}_{3} \mathrm{PO}_{4} / \mathrm{Al}_{2} \mathrm{O}_{3}, \mathrm{Ag}_{2} \mathrm{SO}_{4} / \mathrm{Al}_{2} \mathrm{O}_{3}$ or $\mathrm{AgCl} /$ $\mathrm{Al}_{2} \mathrm{O}_{3}$ was finely ground and placed in a ceramic crucible in the in situ chamber. Mass flow controllers and a sample temperature controller were used to simulate the real reaction conditions, which were the same as those in the catalytic activity tests. Prior to recording each DRIFTS spectrum, the $\mathrm{Ag} / \mathrm{Al}_{2} \mathrm{O}_{3}$ catalyst was heated in situ in a flow of $10 \% \mathrm{O}_{2} / \mathrm{N}_{2}$ at $873 \mathrm{~K}$ for $1 \mathrm{~h}$ and then cooled to the desired temperature to acquire a reference spectrum. All spectra reported here were collected with a resolution of $4 \mathrm{~cm}^{-1}$ for 100 scans.

\section{Theoretical}

The density functional theory (DFT) calculations were carried out using the Gaussian 98 program. The Mulliken charges of $\mathrm{AgCl}$, $\mathrm{Ag}_{2} \mathrm{SO}_{4}, \mathrm{Ag}_{3} \mathrm{PO}_{4}$ and $\mathrm{Ag}_{2} \mathrm{O}$ were calculated using the B3PW91 gradient corrected function (Becke's 3 parameter function with the non-local correlation provided by the Perdew 91 expression). The 3-21G basis set was used for all calculations.

\section{Results and discussion}

\subsection{Activity tests}

Fig. 1 shows the reaction activities of various silver compound catalysts supported on $\mathrm{Al}_{2} \mathrm{O}_{3}$ for the SCR of NOx by ethanol. In all cases, the reaction began at $423 \mathrm{~K}$ and the NOx conversion to $\mathrm{N}_{2}$ was enhanced by the increase of temperature, with the maximum NOx conversion to $\mathrm{N}_{2}$ as high as $99 \%$ at $673 \mathrm{~K}$. It is worth noting that no significant differences in activity were observed among the $\mathrm{Ag} / \mathrm{Al}_{2} \mathrm{O}_{3}, \mathrm{Ag}_{3} \mathrm{PO}_{4} / \mathrm{Al}_{2} \mathrm{O}_{3}$ and $\mathrm{Ag}_{2} \mathrm{SO}_{4} / \mathrm{Al}_{2} \mathrm{O}_{3}$ catalysts over the whole temperature range. Compared to the other three catalysts, the $\mathrm{AgCl} / \mathrm{Al}_{2} \mathrm{O}_{3}$ catalyst gave a $50 \% \mathrm{NOx}$ conversion to $\mathrm{N}_{2}$ at a slightly higher temperature. Considering that the oxidation state of the $\mathrm{Ag}$ in $\mathrm{Ag}_{3} \mathrm{PO}_{4} / \mathrm{Al}_{2} \mathrm{O}_{3}, \mathrm{Ag}_{2} \mathrm{SO}_{4} / \mathrm{Al}_{2} \mathrm{O}_{3}$ and $\mathrm{AgCl} / \mathrm{Al}_{2} \mathrm{O}_{3}$ is +1 throughout,

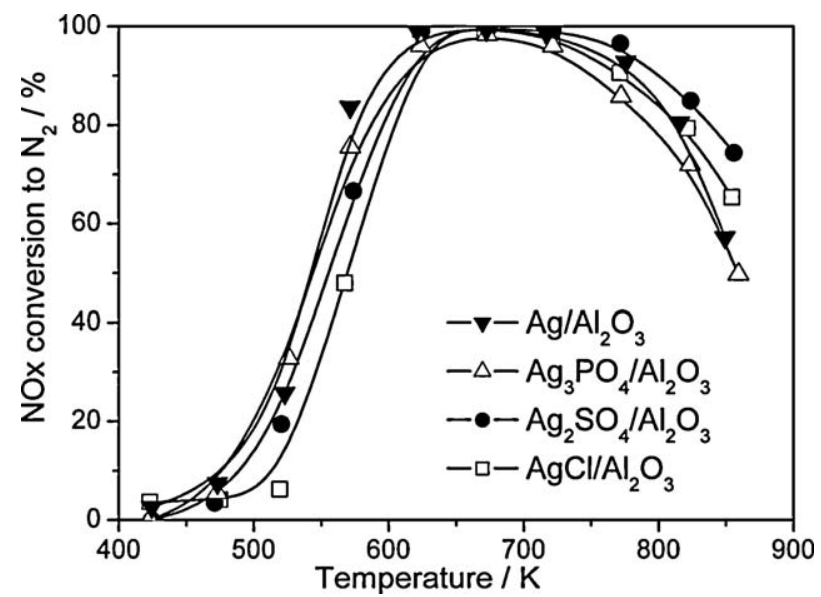

Fig. 1. NOx conversion to $\mathrm{N}_{2}$ for the $\mathrm{SCR}$ of $\mathrm{NOx}$ by $\mathrm{C}_{2} \mathrm{H}_{5} \mathrm{OH}$ over various $\mathrm{Al}_{2} \mathrm{O}_{3}$ supported Ag compound catalysts. Conditions: $800 \mathrm{ppm} \mathrm{NO}, 1565 \mathrm{ppm} \mathrm{C}_{2} \mathrm{H}_{5} \mathrm{OH}$ $10 \% \mathrm{H}_{2} \mathrm{O}, 10 \% \mathrm{O}_{2}$ in $\mathrm{N}_{2}$ balance at a total flow rate of $2000 \mathrm{~cm}^{3} \mathrm{~min}^{-1}, \mathrm{~W}$ $\mathrm{F}=0.018 \mathrm{~g} \mathrm{~s} \mathrm{~cm}^{-3}, \mathrm{GHSV}=\sim 50,000 \mathrm{~h}^{-1}$.

we suppose that the silver in the +1 oxidation state $(\mathrm{Ag}(\mathrm{I}))$ might be the active site of $\mathrm{Ag} / \mathrm{Al}_{2} \mathrm{O}_{3} . \mathrm{N}_{2} \mathrm{O}$, the main nitrogen-containing byproduct during NOx reduction, was also measured on-line. In all cases, only trace amount of $\mathrm{N}_{2} \mathrm{O}$ was measured in the whole temperature range, lower than $10 \mathrm{ppm}$. In addition, the formation of organo-nitrogen compounds was detected by GC-MS. Only trace amount of $\mathrm{CH}_{3} \mathrm{NO}_{2}$ was observed at 473 and $523 \mathrm{~K}$, while trace amount of $\mathrm{CH}_{3} \mathrm{CN}$ was observed at 573 and $623 \mathrm{~K}$. The organonitrogen products were not quantified but this was thought to affect the $\mathrm{N}$ balance to only a minor extent $[8,16]$.

\subsection{Catalyst characterization}

In order to investigate the relationship between the activity and the $\mathrm{Ag}$ state in these catalysts, we performed XRD and BET measurements on various silver catalysts supported on $\mathrm{Al}_{2} \mathrm{O}_{3}$. The structures of the catalysts are revealed by XRD, as shown in Fig. 2. Labels are used to indicate the crystalline structures which exist in each sample. The diffraction peaks observed at $2 \theta=37.0^{\circ}, 45.9^{\circ}$, and $66.8^{\circ}$ are all attributed to crystallized $\gamma-\mathrm{Al}_{2} \mathrm{O}_{3}$ (PDF-ICDD, 770396). No diffraction lines attributable to crystals of metallic $\mathrm{Ag}$, $\mathrm{AgOx}, \mathrm{Ag}_{3} \mathrm{PO}_{4}$ or $\mathrm{Ag}_{2} \mathrm{SO}_{4}$ were observed in the cases of $\mathrm{Ag} / \mathrm{Al}_{2} \mathrm{O}_{3}$, $\mathrm{Ag}_{3} \mathrm{PO}_{4} / \mathrm{Al}_{2} \mathrm{O}_{3}$, and $\mathrm{Ag}_{2} \mathrm{SO}_{4} / \mathrm{Al}_{2} \mathrm{O}_{3}$ catalysts. It should be noted that

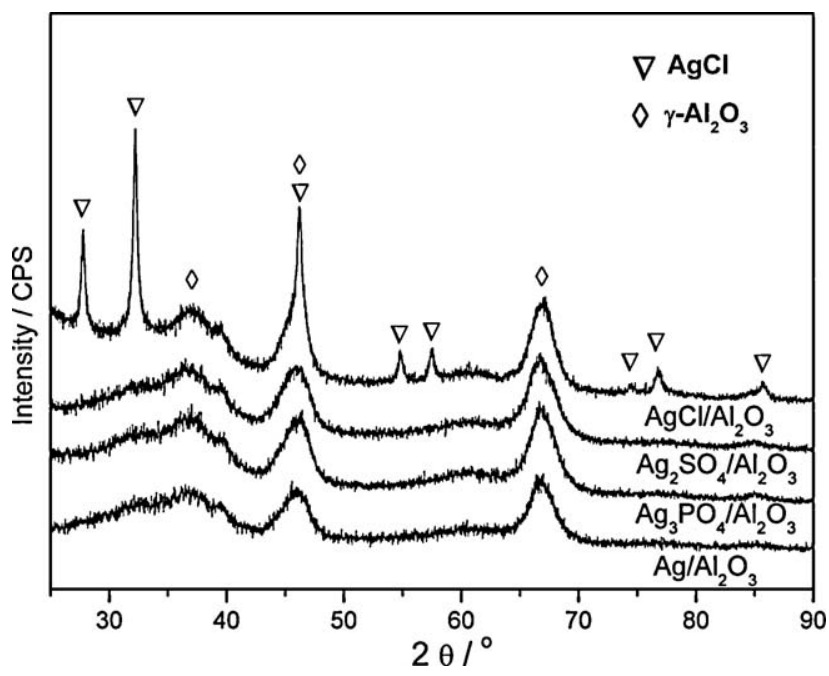

Fig. 2. XRD patterns of the various silver compound catalysts supported on $\mathrm{Al}_{2} \mathrm{O}_{3}$. 
Table 1

The surface areas, the $\mathrm{Ag}$ dispersions, the TOFs, and the Mulliken charges of the various silver compound catalysts supported on $\mathrm{Al}_{2} \mathrm{O}_{3}$.

\begin{tabular}{|c|c|c|c|c|}
\hline Catalysts & $\mathrm{Ag} / \mathrm{Al}_{2} \mathrm{O}_{3}$ & $\mathrm{Ag}_{3} \mathrm{PO}_{4} / \mathrm{Al}_{2} \mathrm{O}_{3}$ & $\mathrm{Ag}_{2} \mathrm{SO}_{4} / \mathrm{Al}_{2} \mathrm{O}_{3}$ & $\mathrm{AgCl} / \mathrm{Al}_{2} \mathrm{O}_{3}$ \\
\hline Surface area $\left(\mathrm{m}^{2} \mathrm{~g}^{-1}\right)$ & 254.8 & 255.1 & 238.0 & 224.9 \\
\hline $\mathrm{Ag}$ dispersion $(\%)$ & 12.6 & 6.1 & 5.2 & 0.6 \\
\hline NOx conversion $(\%, 523 \mathrm{~K})$ & 26 & 33 & 19 & 6 \\
\hline TOF $\left(10^{-2} \mathrm{~s}^{-1}\right)$ for NOx reduction & 1.1 & 2.9 & 2.0 & 6.0 \\
\hline Mulliken charges of Ag in silver compounds ${ }^{*}$ & $0.215^{\mathrm{a}}$ & $0.378^{\mathrm{b}}$ & $0.421^{\mathrm{c}}$ & $0.503^{d}$ \\
\hline
\end{tabular}

* The average Mulliken charges of $\mathrm{Ag}$ in $\mathrm{Ag}_{2} \mathrm{O}^{\mathrm{a}}, \mathrm{Ag}_{3} \mathrm{PO}_{4}{ }^{\mathrm{b}}, \mathrm{Ag}_{2} \mathrm{SO}_{4}{ }^{\mathrm{c}}$, and $\mathrm{AgCl}^{\mathrm{d}}$.

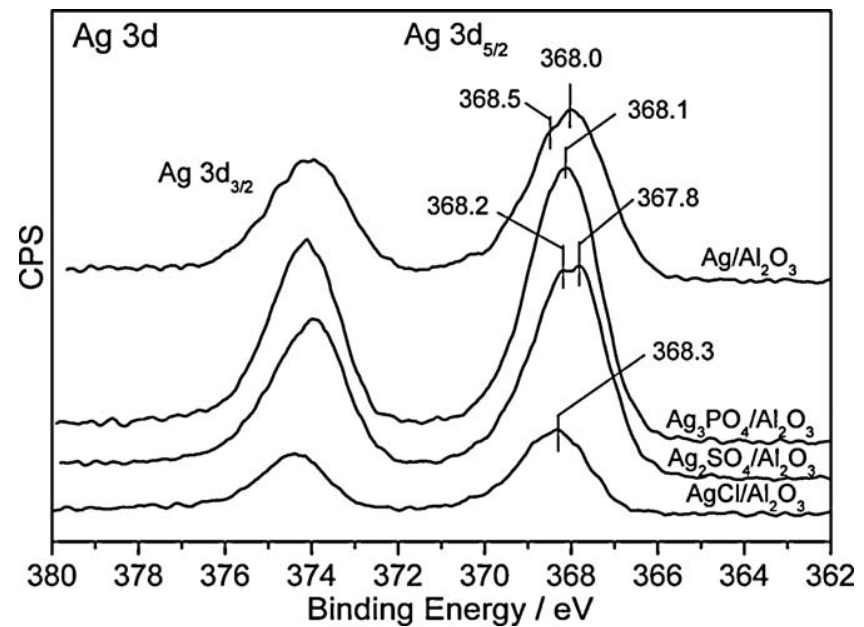

Fig. 3. High-resolution XPS spectra of the $\mathrm{Ag} 3 \mathrm{~d}$ level for the various silver compound catalysts supported on $\mathrm{Al}_{2} \mathrm{O}_{3}$.

the $\mathrm{Ag}_{3} \mathrm{PO}_{4} / \mathrm{Al}_{2} \mathrm{O}_{3}$ catalyst shows a faint yellow color after calcination at $873 \mathrm{~K}$, indicating the presence of $\mathrm{Ag}_{3} \mathrm{PO}_{4}$. Considering that $\mathrm{AgCl}, \mathrm{Ag}_{3} \mathrm{PO}_{4}$ and $\mathrm{Ag}_{2} \mathrm{SO}_{4}$ could not have been decomposed at the calcination temperature $(873 \mathrm{~K})$, it is obvious that $\mathrm{Ag}$, $\mathrm{Ag}_{3} \mathrm{PO}_{4}$ and $\mathrm{Ag}_{2} \mathrm{SO}_{4}$ are highly dispersed on the $\gamma-\mathrm{Al}_{2} \mathrm{O}_{3}$ [27-29]. However, the obvious XRD peaks attributable to crystallized $\mathrm{AgCl}$ were observed at $2 \theta=32.2^{\circ}$ for the $\mathrm{AgCl} / \mathrm{Al}_{2} \mathrm{O}_{3}$ catalyst [27], which indicates the lower dispersion of $\mathrm{Ag}(\mathrm{I})$ in comparison with the other three catalysts. The BET surface areas of the catalysts are presented in Table 1 . It is obvious that $\mathrm{Ag} / \mathrm{Al}_{2} \mathrm{O}_{3}$ and $\mathrm{Ag}_{3} \mathrm{PO}_{4} / \mathrm{Al}_{2} \mathrm{O}_{3}$ have similar surface areas, followed by $\mathrm{Ag}_{2} \mathrm{SO}_{4} / \mathrm{Al}_{2} \mathrm{O}_{3}$, while $\mathrm{AgCl} /$ $\mathrm{Al}_{2} \mathrm{O}_{3}$ has the smallest surface area. The lower dispersion of $\mathrm{AgCl}$ on $\mathrm{Al}_{2} \mathrm{O}_{3}$ and lower surface area could account for the slight decrease of the apparent activity for NOx reduction over $\mathrm{AgCl} / \mathrm{Al}_{2} \mathrm{O}_{3}$ in the temperature range 473-623 $\mathrm{K}$ (Fig. 1).

Table 1 also shows the Ag dispersions of the four catalysts and their TOFs for NOx reduction at $523 \mathrm{~K}$. The Ag dispersions and the TOFs were calculated based on formulae (1) and (2) shown in Section 2, respectively. It is clear that the dispersion of $\mathrm{Ag}$ on the surface follows the order of $\mathrm{Ag} / \mathrm{Al}_{2} \mathrm{O}_{3}>\mathrm{Ag}_{3} \mathrm{PO}_{4} / \mathrm{Al}_{2} \mathrm{O}_{3}>\mathrm{Ag}_{2} \mathrm{SO}_{4} /$
$\mathrm{Al}_{2} \mathrm{O}_{3}>\mathrm{AgCl} / \mathrm{Al}_{2} \mathrm{O}_{3}$. The lowest $\mathrm{Ag}$ dispersion (for the $\mathrm{AgCl} / \mathrm{Al}_{2} \mathrm{O}_{3}$ catalyst) is in agreement with the XRD result of $\mathrm{AgCl} / \mathrm{Al}_{2} \mathrm{O}_{3}$. The order of TOFs is $\mathrm{AgCl} / \mathrm{Al}_{2} \mathrm{O}_{3} \gg \mathrm{Ag}_{3} \mathrm{PO}_{4} / \mathrm{Al}_{2} \mathrm{O}_{3}>\mathrm{Ag}_{2} \mathrm{SO}_{4} / \mathrm{Al}_{2} \mathrm{O}_{3}>\mathrm{Ag} /$ $\mathrm{Al}_{2} \mathrm{O}_{3}$. In particular, the TOF of $\mathrm{AgCl} / \mathrm{Al}_{2} \mathrm{O}_{3}$ for NOx reduction is 5 times higher than $\mathrm{Ag} / \mathrm{Al}_{2} \mathrm{O}_{3}$, while $\mathrm{Ag}_{3} \mathrm{PO}_{4} / \mathrm{Al}_{2} \mathrm{O}_{3}$ and $\mathrm{Ag}_{2} \mathrm{SO}_{4} / \mathrm{Al}_{2} \mathrm{O}_{3}$ give similar values, also twice higher than $\mathrm{Ag} / \mathrm{Al}_{2} \mathrm{O}_{3}$. These results indicate that the anions associated with the silver ion have a significant positive influence on the SCR of NOx by $\mathrm{C}_{2} \mathrm{H}_{5} \mathrm{OH}$, which may be owing to the high polarity of $\mathrm{AgCl}, \mathrm{Ag}_{3} \mathrm{PO}_{4}$ and $\mathrm{Ag}_{2} \mathrm{SO}_{4}$ and finally relative to a strong stabilization of $\mathrm{Ag}(\mathrm{I})$ [32]. To clarify this hypothesis, we calculated the Mulliken charges of $\mathrm{Ag}$ in $\mathrm{Ag}_{2} \mathrm{O}$, $\mathrm{Ag}_{3} \mathrm{PO}_{4}, \mathrm{Ag}_{2} \mathrm{SO}_{4}$ and $\mathrm{AgCl}$ based on DFT theory; the results are shown in Table 1. Obviously, the average Mulliken charges of $\mathrm{Ag}$ in the four silver compounds follow the same order of TOFs for NOx reduction: $\mathrm{AgCl}(0.503)>\mathrm{Ag}_{2} \mathrm{SO}_{4}(0.421) \approx \mathrm{Ag}_{3} \mathrm{PO}_{4}(0.378)>\mathrm{Ag}_{2} \mathrm{O}$ (0.215), exactly interpreting the positive effects of anions on the intrinsic activities of the four catalysts. That is, chloride gives much stronger electron withdrawing ability to keep the highly positive charge on $\mathrm{Ag}$ in $\mathrm{AgCl}$, which is more favorable for stabilizing the oxidation of $\mathrm{Ag}$ and obtaining a high TOF for $\mathrm{AgCl} / \mathrm{Al}_{2} \mathrm{O}_{3}$.

The $\mathrm{Ag}$ valence state of the supported $\mathrm{Ag}$ was further characterized by high-resolution XPS, with the results shown in Fig. 3 and summarized in Table 2. As can be seen in Fig. 3, the peaks of the $A g 3 \mathrm{~d}_{5 / 2}$ binding energy for all samples appeared at around 367.8-368.3 eV. As reported by Hammond et al. [33], Ag is unusual in that its core-level photoemissions shift to lower binding energy with increasing oxidation state. The binding energies of $\mathrm{Ag} 3 \mathrm{~d}_{5 / 2}$ in $\mathrm{Ag} / \mathrm{Al}_{2} \mathrm{O}_{3}, \mathrm{Ag}_{3} \mathrm{PO}_{4} / \mathrm{Al}_{2} \mathrm{O}_{3}, \mathrm{Ag}_{2} \mathrm{SO}_{4} / \mathrm{Al}_{2} \mathrm{O}_{3}$ and $\mathrm{AgCl} / \mathrm{Al}_{2} \mathrm{O}_{3}$ are 368.0, $368.1,368.2$ and $368.3 \mathrm{eV}$, respectively, which are consistent with the binding energies of $\mathrm{Ag}_{3 / 2}$ in $\mathrm{Ag}_{2} \mathrm{O}, \mathrm{Ag}_{3} \mathrm{PO}_{4}, \mathrm{Ag}_{2} \mathrm{SO}_{4}$ and $\mathrm{AgCl}$ according to the literature values of $367.9 \mathrm{eV}$ [34], $368.2 \mathrm{eV}$ [35], $368.3 \mathrm{eV}$ [36] and $368.1 \mathrm{eV}$ [37]. In addition, a shoulder at $368.5 \mathrm{eV}$ for $\mathrm{Ag} / \mathrm{Al}_{2} \mathrm{O}_{3}$ might be attributed to $\mathrm{Ag}^{0}\left(\mathrm{Ag} 3 \mathrm{~d}_{5 / 2}=368.4 \mathrm{eV}\right)$ [38] on the surface. As for $\mathrm{Ag}_{2} \mathrm{SO}_{4} / \mathrm{Al}_{2} \mathrm{O}_{3}$, another peak of $\mathrm{Ag} 3 \mathrm{~d}_{5 / 2}$ is present at $367.8 \mathrm{eV}$, indicating that some of the loaded $\mathrm{Ag}$ in $\mathrm{Ag}_{2} \mathrm{SO}_{4} / \mathrm{Al}_{2} \mathrm{O}_{3}$ could exist in the form of $\mathrm{Ag}_{2} \mathrm{O}\left(\mathrm{Ag} 3 \mathrm{~d}_{5 / 2}=367.9 \mathrm{eV}\right)$ [34]. In addition, the apparent surface $\mathrm{Ag}$ content was estimated from the integrated peak area of $\mathrm{Ag} 3 \mathrm{~d}_{5 / 2}$ relative to that of all elements on each catalyst, as shown in Table 2 . The order of apparent surface $\mathrm{Ag}$ content ( $\mathrm{Ag}$ at.\%) for the four catalysts is as follows: $\mathrm{Ag}_{3} \mathrm{PO}_{4} / \mathrm{Al}_{2} \mathrm{O}_{3}>\mathrm{Ag}_{2} \mathrm{SO}_{4} / \mathrm{Al}_{2} \mathrm{O}_{3}>\mathrm{Ag} / \mathrm{Al}_{2} \mathrm{O}_{3}>\mathrm{AgCl} / \mathrm{Al}_{2} \mathrm{O}_{3}$.

Table 2

Characteristics of the Ag species in the silver compound catalysts as analyzed with XPS.

\begin{tabular}{|c|c|c|c|c|}
\hline \multirow[t]{2}{*}{ Catalysts } & \multicolumn{2}{|c|}{ Binding energy (eV) } & \multirow[t]{2}{*}{ Apparent surface Ag content (at.\%) } & \multirow{2}{*}{$\begin{array}{l}\text { Ref. } \\
\text { Binding energy of } \mathrm{Ag} 3 \mathrm{~d}_{5 / 2}(\mathrm{eV})\end{array}$} \\
\hline & $\mathrm{Ag} 3 \mathrm{~d}_{5 / 2}$ & $01 \mathrm{~s}$ & & \\
\hline $\mathrm{Ag} / \mathrm{Al}_{2} \mathrm{O}_{3}$ & $\begin{array}{l}368.0 \\
368.5\end{array}$ & 531.2 & 0.76 & $\begin{array}{l}\mathrm{Ag}_{2} \mathrm{O} 367.9 \mathrm{eV}[34] \\
\mathrm{Ag} 368.4 \mathrm{eV} \mathrm{[38]}\end{array}$ \\
\hline $\mathrm{Ag}_{3} \mathrm{PO}_{4} / \mathrm{Al}_{2} \mathrm{O}_{3}$ & 368.1 & 531.4 & 1.5 & $\mathrm{Ag}_{3} \mathrm{PO}_{4} 368.2 \mathrm{eV}[35]$ \\
\hline $\mathrm{Ag}_{2} \mathrm{SO}_{4} / \mathrm{Al}_{2} \mathrm{O}_{3}$ & $\begin{array}{l}368.2 \\
367.8\end{array}$ & 531.3 & 1.1 & $\begin{array}{l}\mathrm{Ag}_{2} \mathrm{SO}_{4} 368.3 \mathrm{eV}[36] \\
\mathrm{Ag}_{2} \mathrm{O} 367.9 \mathrm{eV}[34]\end{array}$ \\
\hline $\mathrm{AgCl} / \mathrm{Al}_{2} \mathrm{O}_{3}$ & 368.3 & 531.4 & 0.5 & $\mathrm{AgCl} 368.1 \mathrm{eV}$ [37] \\
\hline
\end{tabular}

\footnotetext{
${ }^{\text {a }}$ Atomic ratio corresponds to the ratio of apparent surface element content (at.\%).
} 
On the basis of the above characterizations, it is confirmed that the highly dispersed +1 oxide state silver species on the four silver catalysts are the active sites for the SCR of NOx by ethanol. Furthermore, it is proposed that using silver precipitable compounds to prepare $\mathrm{Ag}$ catalysts may provide a method to fix and stabilize the silver species in the +1 oxide state.

\subsection{In situ DRIFTS studies}

\subsubsection{The formation of enolic species on silver compound catalysts supported on $\mathrm{Al}_{2} \mathrm{O}_{3}$}

The enolic species, originating from the partial oxidation of $\mathrm{C}_{2} \mathrm{H}_{5} \mathrm{OH}$ during the SCR, play an important role in the formation of the $-\mathrm{NCO}$ species as a key intermediate $[24,25,39]$. In our previous studies, we have proved that Ag participated in the formation of the adsorbed enolic species based on the results of DFT calculations of the vibrational frequencies and in situ DRIFTS spectra $[25,39]$. Therefore, we investigated the formation of enolic species on the various silver compound catalysts. Fig. 4(a)-(c) shows the in situ DRIFTS spectra of $\mathrm{Ag}_{3} \mathrm{PO}_{4} / \mathrm{Al}_{2} \mathrm{O}_{3}, \mathrm{Ag}_{2} \mathrm{SO}_{4} / \mathrm{Al}_{2} \mathrm{O}_{3}$ and $\mathrm{AgCl} / \mathrm{Al}_{2} \mathrm{O}_{3}$, respectively, in a flow of $\mathrm{C}_{2} \mathrm{H}_{5} \mathrm{OH}+\mathrm{O}_{2}$ over the temperature range 473-773 $\mathrm{K}$ in the steady state. As shown in Fig. 4(a), peaks at 1633, $1579,1466,1416$ and $1336 \mathrm{~cm}^{-1}$ were observed on the surface of $\mathrm{Ag}_{3} \mathrm{PO}_{4} / \mathrm{Al}_{2} \mathrm{O}_{3}$, which are similar to those on the surface of $\mathrm{Ag} / \mathrm{Al}_{2} \mathrm{O}_{3}$ found from our previous studies $[24,25,39]$. These peaks can be assigned to enolic species $\left(1633,1416\right.$ and $\left.1336 \mathrm{~cm}^{-1}\right)[24,25,39]$ and acetate (1579 and $1466 \mathrm{~cm}^{-1}$ ) $[8,9,40]$. Comparing the peak intensities of enolic species and acetate, we find that the enolic species was the main species in the temperature range of 523$773 \mathrm{~K}$. For $\mathrm{Ag}_{2} \mathrm{SO}_{4} / \mathrm{Al}_{2} \mathrm{O}_{3}$ and $\mathrm{AgCl} / \mathrm{Al}_{2} \mathrm{O}_{3}$ in Fig. 4(b) and (c), the adsorption peaks assigned to the enolic species $(1633,1416-1417$ and $1327-1336 \mathrm{~cm}^{-1}$ ) [24,25,39] and acetate (1576-1579 and $\left.1464-1468 \mathrm{~cm}^{-1}\right)[8,9,40]$ were all visible in the temperature range of $473-773 \mathrm{~K}$. It is reasonable that surface species on these catalysts show some similarity, because the $\mathrm{Ag}$ in all catalysts is in the +1 oxidation state, as discussed above. It is worth noting that the temperature range for which the enolic species was the main species was different for the three catalysts, that is, $523-773 \mathrm{~K}$ for $\mathrm{Ag}_{3} \mathrm{PO}_{4} / \mathrm{Al}_{2} \mathrm{O}_{3}$ and $\mathrm{Ag}_{2} \mathrm{SO}_{4} / \mathrm{Al}_{2} \mathrm{O}_{3}$, and $623-773 \mathrm{~K}$ for $\mathrm{AgCl} / \mathrm{Al}_{2} \mathrm{O}_{3}$. Considering the different degrees of $\mathrm{Ag}$ dispersion on the various catalysts (Table 1 ), we conclude that highly dispersed $\mathrm{Ag}(\mathrm{I})$ is favorable for the formation of the enolic species.

\subsubsection{Reaction mechanism of $\mathrm{C}_{2} \mathrm{H}_{5} \mathrm{OH}$-SCR of NOx over the silver compound catalysts supported on $\mathrm{Al}_{2} \mathrm{O}_{3}$}

It was reported that the $-\mathrm{NCO}$ species was a vital intermediate for the SCR of NOx over $\mathrm{Ag} / \mathrm{Al}_{2} \mathrm{O}_{3}$, and its high reactivity resulted in a high efficiency of NOx reduction by $\mathrm{C}_{2} \mathrm{H}_{5} \mathrm{OH}$ or hydrocarbons $[6,8,19,40-43]$. In our previous studies $[24,25,39]$, it was found that the enolic species has a higher reactivity with $\mathrm{NO}+\mathrm{O}_{2}$ than acetate to form the surface $-\mathrm{NCO}$ species over $\mathrm{Ag} / \mathrm{Al}_{2} \mathrm{O}_{3}$. In order to obtain the information on the reactivity of the surface enolic species over silver compounds supported on $\mathrm{Al}_{2} \mathrm{O}_{3}$, transient response experiments using in situ DRIFTS were performed. Fig. 5(a) shows the dynamic changes of in situ DRIFTS spectra of the adsorbed species on $\mathrm{Ag}_{3} \mathrm{PO}_{4} / \mathrm{Al}_{2} \mathrm{O}_{3}$ in a flow of $\mathrm{NO}+\mathrm{O}_{2}$ at $673 \mathrm{~K}$. After exposing the catalyst to the flow of $\mathrm{C}_{2} \mathrm{H}_{5} \mathrm{OH}+\mathrm{O}_{2}$ for $60 \mathrm{~min}$, very strong enolic species peaks were observed at 1633,1416 and $1336 \mathrm{~cm}^{-1}$, and acetate peaks were also observed at 1576 and $1464 \mathrm{~cm}^{-1}$. Switching the feed gas to a flow of $\mathrm{NO}+\mathrm{O}_{2}$ resulted in the disappearance of the enolic species in $5 \mathrm{~min}$. At the same time, new peaks appeared at 2231 and $2254 \mathrm{~cm}^{-1}$, which are assigned to $\mathrm{Ag}-$ NCO and Al-NCO $[6,8,19,40-43]$. With the reaction time prolonged, the peaks at 1589 and $1300 \mathrm{~cm}^{-1}$ for nitrate appeared $[8,15,41,42]$. It is noticed that the intensity of the -NCO species initially increased, reached a maximum, then decreased. The
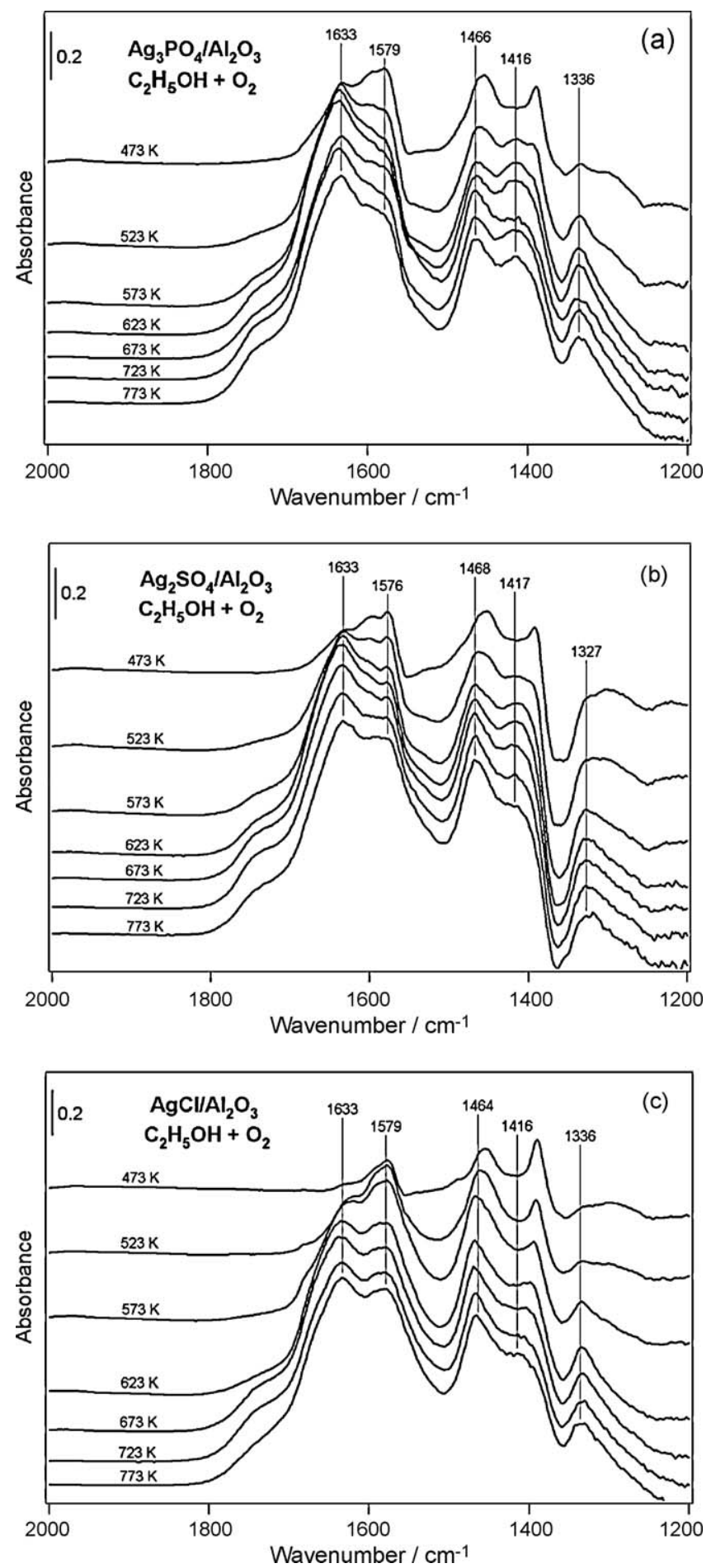

Fig. 4. In situ DRIFTS spectra of the silver compound catalysts supported on $\mathrm{Al}_{2} \mathrm{O}_{3}$ at various temperatures in a flow of $\mathrm{C}_{2} \mathrm{H}_{5} \mathrm{OH}+\mathrm{O}_{2}$. (a) $\mathrm{Ag}_{3} \mathrm{PO}_{4} / \mathrm{Al}_{2} \mathrm{O}_{3}$; (b) $\mathrm{Ag}_{2} \mathrm{SO}_{4} / \mathrm{Al}_{2} \mathrm{O}_{3}$; (c) $\mathrm{AgCl} / \mathrm{Al}_{2} \mathrm{O}_{3}$. Conditions: $\mathrm{C}_{2} \mathrm{H}_{5} \mathrm{OH}, 1565 \mathrm{ppm} ; \mathrm{O}_{2}, 10 \% ; \mathrm{N}_{2}$ balance.

integrated areas of the peaks in Fig. 5(a) are displayed as a function of time in Fig. 5(b). Similar results were observed with the $\mathrm{Ag}_{2} \mathrm{SO}_{4} /$ $\mathrm{Al}_{2} \mathrm{O}_{3}$ and $\mathrm{AgCl} / \mathrm{Al}_{2} \mathrm{O}_{3}$ catalysts (results not shown). The connection between the formation of the -NCO species and the consumption of the enolic species strongly suggests the participation of the enolic species in the formation of the -NCO species, which further confirms our previous conclusion [24,25,39].

Based on the above results, the reaction mechanism of $\mathrm{C}_{2} \mathrm{H}_{5} \mathrm{OH}-$ SCR of NOx was further investigated on the various silver 

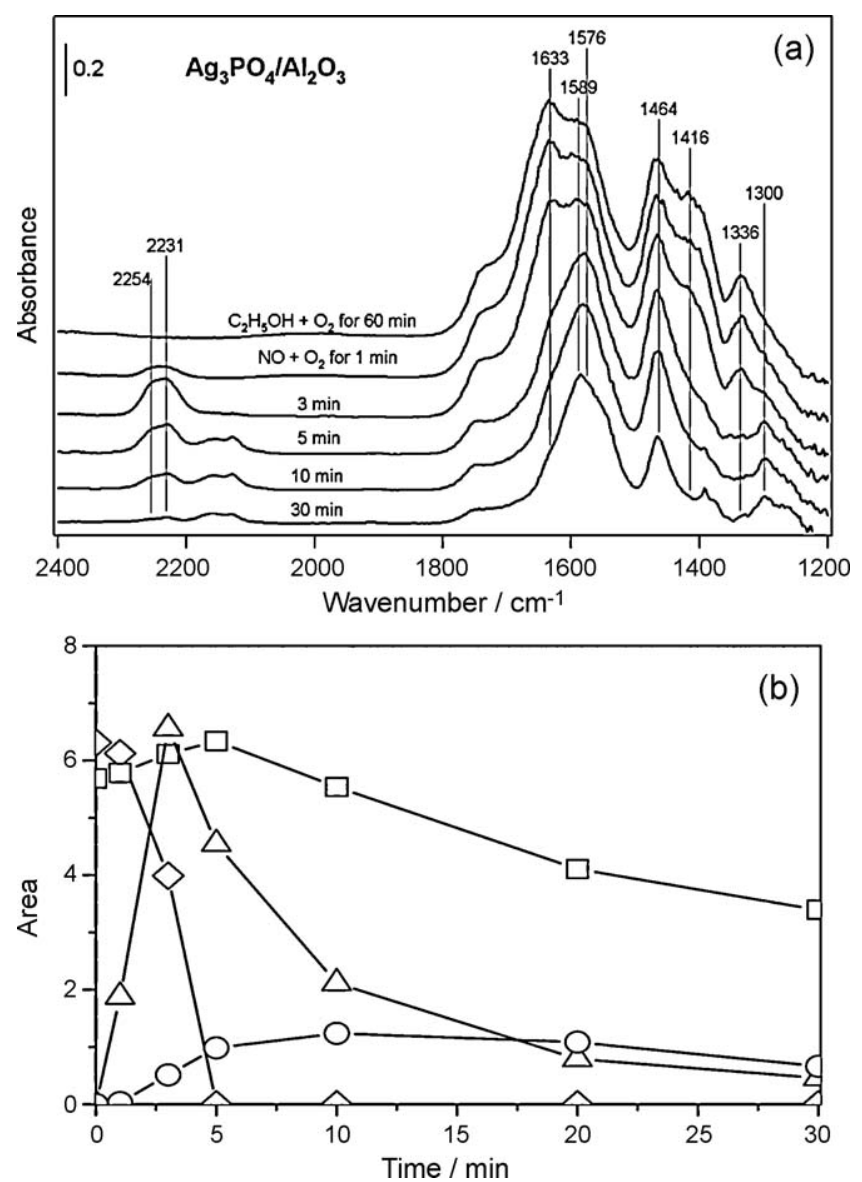

Fig. 5. (a) Dynamic changes of in situ DRIFTS spectra of the adsorbed enolic species on $\mathrm{Ag}_{3} \mathrm{PO}_{4} / \mathrm{Al}_{2} \mathrm{O}_{3}$ as a function of time in a flow of $\mathrm{NO}+\mathrm{O}_{2}$ at $673 \mathrm{~K}$. Before the measurement, the catalyst was pre-exposed to a flow of $\mathrm{C}_{2} \mathrm{H}_{5} \mathrm{OH}+\mathrm{O}_{2}$ for $60 \mathrm{~min}$ at $673 \mathrm{~K}$. Conditions: $\mathrm{C}_{2} \mathrm{H}_{5} \mathrm{OH}, 1565$ ppm; NO, 800 ppm; $\mathrm{O}_{2}, 10 \% ; \mathrm{N}_{2}$ balance. (b) Time dependence of the integrated areas of the peaks for different adsorbed species in (a): $(\Delta)$-NCO, 2197-2297 $\mathrm{cm}^{-1}$; $(\diamond)$ enolic species, $1363-1437 \mathrm{~cm}^{-1}$; $\square$ ) acetate, $1446-1500 \mathrm{~cm}^{-1}$; (○) nitrates, $1270-1313 \mathrm{~cm}^{-1}$.

compound catalysts by in situ steady state DRIFTS. Fig. 6(a)-(c) shows the in situ DRIFTS spectra of three silver compound catalysts in a flow of $\mathrm{NO}+\mathrm{C}_{2} \mathrm{H}_{5} \mathrm{OH}+\mathrm{O}_{2}$ over the temperature range of 473$873 \mathrm{~K}$ in the steady state. In the case of $\mathrm{Ag}_{3} \mathrm{PO}_{4} / \mathrm{Al}_{2} \mathrm{O}_{3}$ (Fig. 6(a)), several peaks appeared in the region of $1200-1800 \mathrm{~cm}^{-1}$; these peaks are attributed to the enolic species (1633, 1417 and $\left.1336 \mathrm{~cm}^{-1}\right)$ [24,25,39], acetate $\left(1576\right.$ and $\left.1464 \mathrm{~cm}^{-1}\right)[8,9,40]$ and nitrate $\left(1589\right.$ and $\left.1300 \mathrm{~cm}^{-1}\right)[8,15,41,42]$. In the range of $2400-2000 \mathrm{~cm}^{-1}$, the -CN species $\left(2158 \mathrm{~cm}^{-1}\right)$ was visible at $473-$ $773 \mathrm{~K} ; \mathrm{Ag}-\mathrm{NCO}\left(2231 \mathrm{~cm}^{-1}\right)$ was present at $523-773 \mathrm{~K}$ and $\mathrm{Al}-$ NCO $\left(2254 \mathrm{~cm}^{-1}\right)$ was observed at $523-573 \mathrm{~K}[6,8,19,40-43]$. Similar results were observed for $\mathrm{Ag}_{2} \mathrm{SO}_{4} / \mathrm{Al}_{2} \mathrm{O}_{3}$, as shown in Fig. 6(b). However, for the $\mathrm{AgCl} / \mathrm{Al}_{2} \mathrm{O}_{3}$ catalyst in Fig. 6(c), no obvious -CN species $\left(2158 \mathrm{~cm}^{-1}\right)$ appeared, while Al-NCO $\left(2254 \mathrm{~cm}^{-1}\right)$ appeared at $573-673 \mathrm{~K}$, and Ag-NCO $\left(2231 \mathrm{~cm}^{-1}\right)$ was present at 723-773 K. It is supposed that the formation of bulk $\mathrm{AgCl}$ crystal lowered the dispersion of $\mathrm{Ag}$ and led to the low surface concentration of $\mathrm{Ag}-\mathrm{NCO}$, which was responsible for the somewhat lower apparent activity in the low temperature region 473$573 \mathrm{~K}$ as compared with the other three catalysts (Fig. 1). Based on the above results, we can conclude that the reaction mechanism of $\mathrm{C}_{2} \mathrm{H}_{5} \mathrm{OH}$-SCR of NOx over the $\mathrm{Al}_{2} \mathrm{O}_{3}$-supported silver precipitable compound catalysts is very similar to that over the $\mathrm{Ag} / \mathrm{Al}_{2} \mathrm{O}_{3}$ catalyst $[14,15,24,25,39]$, and that the high dispersion of $\mathrm{Ag}(\mathrm{I})$ favored the reaction.
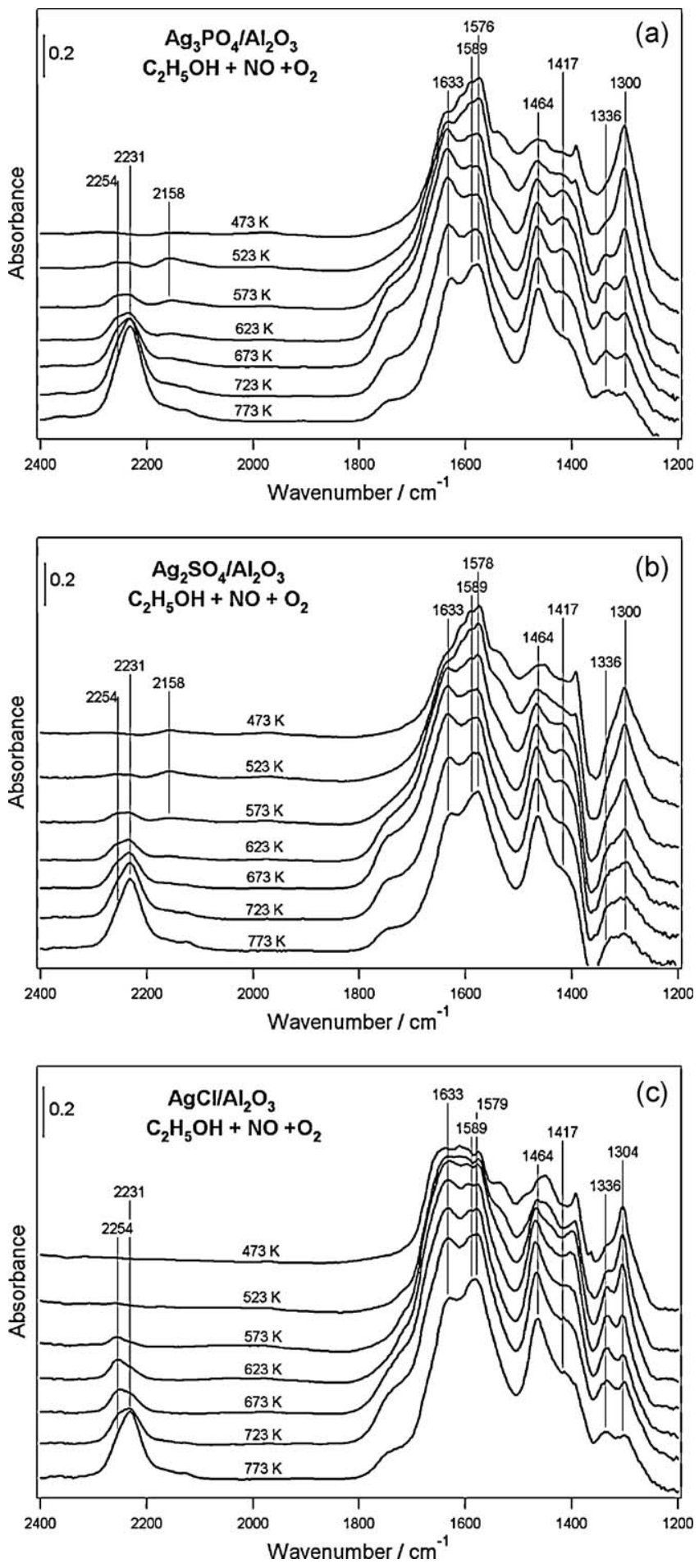

Fig. 6. In situ DRIFTS spectra of the silver compound catalysts supported on $\mathrm{Al}_{2} \mathrm{O}_{3}$ at various temperatures in a flow of $\mathrm{NO}+\mathrm{C}_{2} \mathrm{H}_{5} \mathrm{OH}+\mathrm{O}_{2}$. (a) $\mathrm{Ag}_{3} \mathrm{PO}_{4} / \mathrm{Al}_{2} \mathrm{O}_{3}$; (b) $\mathrm{Ag}_{2} \mathrm{SO}_{4} /$ $\mathrm{Al}_{2} \mathrm{O}_{3}$; (c) $\mathrm{AgCl} / \mathrm{Al}_{2} \mathrm{O}_{3}$. Conditions: NO, 800 ppm; $\mathrm{C}_{2} \mathrm{H}_{5} \mathrm{OH}, 1565 \mathrm{ppm} ; \mathrm{O}_{2}, 10 \% ; \mathrm{N}_{2}$ balance.

\subsection{Washcoated honeycomb catalyst tests}

On the basis of the above investigation, the $\mathrm{Ag}_{3} \mathrm{PO}_{4} / \mathrm{Al}_{2} \mathrm{O}_{3}$ and $\mathrm{AgCl} / \mathrm{Al}_{2} \mathrm{O}_{3}$ washcoated honeycomb catalysts with stable properties were prepared, and activity tests for the SCR of NOx by ethanol were performed under the same conditions as for the powder catalysts, as shown in Fig. 7 , respectively. The $\mathrm{Ag}_{3} \mathrm{PO}_{4} / \mathrm{Al}_{2} \mathrm{O}_{3}$ and $\mathrm{AgCl} / \mathrm{Al}_{2} \mathrm{O}_{3}$ washcoated honeycomb catalysts were tested under 


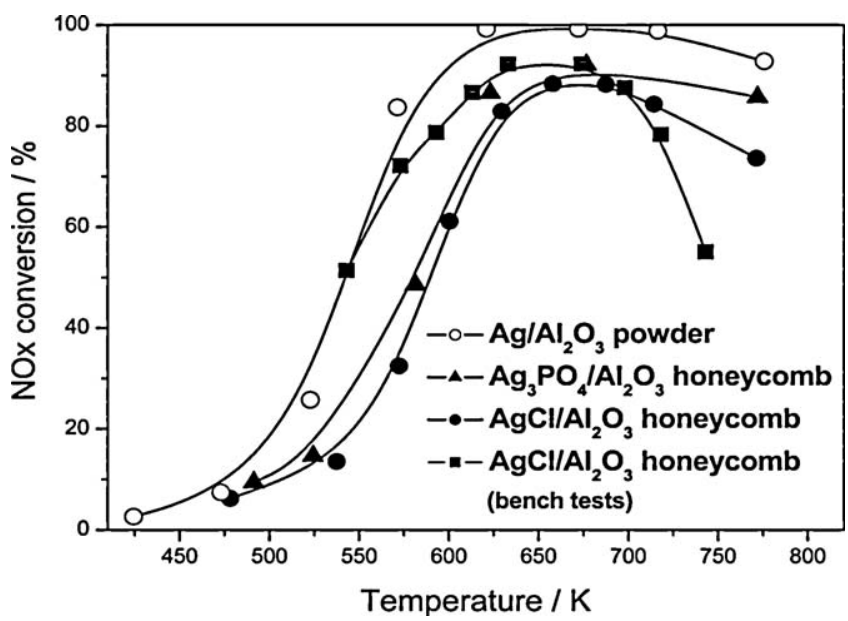

Fig. 7. $\mathrm{NOx}$ conversions for the SCR of $\mathrm{NOx}$ by $\mathrm{C}_{2} \mathrm{H}_{5} \mathrm{OH}$ over the (O) $\mathrm{Ag} / \mathrm{Al}_{2} \mathrm{O}_{3}$ powder catalyst, $(\boldsymbol{\Delta}) \mathrm{Ag}_{3} \mathrm{PO}_{4} / \mathrm{Al}_{2} \mathrm{O}_{3}$ washcoated honeycomb catalyst, $(\bullet) \mathrm{AgCl} /$ $\mathrm{Al}_{2} \mathrm{O}_{3}$ washcoated honeycomb catalyst, and (ם) $\mathrm{AgCl} / \mathrm{Al}_{2} \mathrm{O}_{3}$ washcoated honeycomb catalyst bench tested on a diesel engine. Conditions: $800 \mathrm{ppm}$ NO, $1565 \mathrm{ppm} \mathrm{C}_{2} \mathrm{H}_{5} \mathrm{OH}, 10 \% \mathrm{H}_{2} \mathrm{O}, 10 \% \mathrm{O}_{2}, \mathrm{~N}_{2}$ balance, GHSV $=\sim 50,000 \mathrm{~h}^{-1}$ or $\mathrm{GHSV}=\sim 30,000 \mathrm{~h}^{-1}$ (bench tests).

$50,000 \mathrm{~h}^{-1}$ of GHSV and $0.008 \mathrm{~g} \mathrm{~s} \mathrm{~cm}^{-3}$ of $\mathrm{W} / \mathrm{F}$, while the powder $\mathrm{Ag} / \mathrm{Al}_{2} \mathrm{O}_{3}$ catalyst was tested under $50,000 \mathrm{~h}^{-1}$ of GHSV and $0.018 \mathrm{~g} \mathrm{~s} \mathrm{~cm}^{-3}$ of W/F. As expected, the NOx conversions over the washcoated honeycomb catalysts were similar to those with the $\mathrm{Ag} / \mathrm{Al}_{2} \mathrm{O}_{3}$ powder catalyst (shown in Fig. 7). Of course, the maximum NOx conversion by the honeycomb catalysts decreased slightly compared to that of the powder catalysts, which is reasonable due to the shape difference and lower $\mathrm{W} / \mathrm{F}$ values.

Since the precipitable silver compounds can be used as the active sites on $\mathrm{Al}_{2} \mathrm{O}_{3}$ for $\mathrm{NOx}$ reduction, this gives great opportunities for the preparation of monolith $\mathrm{Ag} / \mathrm{Al}_{2} \mathrm{O}_{3}$ catalysts for practical use. Based on laboratory studies, a bench test was carried out using the monolith $\mathrm{AgCl} / \mathrm{Al}_{2} \mathrm{O}_{3}$ washcoated honeycomb catalyst and $\mathrm{C}_{2} \mathrm{H}_{5} \mathrm{OH}$ as a reducing agent with a heavy duty diesel engine operating under practical conditions, as shown in Fig. 7, and a good performance was obtained. At the typical diesel engine exhaust temperature range, the conversion of NOx remained rather high at a GHSV of $\sim 30,000 \mathrm{~h}^{-1}\left(\mathrm{~W} / \mathrm{F}=0.013 \mathrm{~g} \mathrm{~s} \mathrm{~cm}^{-3}\right)$. The highest NOx conversion reached $92.3 \%$ at an operating temperature of $673 \mathrm{~K}$. The results are very close to the laboratory results, indicating the potential applicability for NOx reduction under real diesel engine exhaust conditions.

\section{Conclusions}

The activity of $\mathrm{Ag}(\mathrm{I})$ on various silver precipitable compound catalysts supported on $\mathrm{Al}_{2} \mathrm{O}_{3}\left(\mathrm{Ag}_{3} \mathrm{PO}_{4} / \mathrm{Al}_{2} \mathrm{O}_{3}, \mathrm{Ag}_{2} \mathrm{SO}_{4} / \mathrm{Al}_{2} \mathrm{O}_{3}\right.$ and $\mathrm{AgCl} / \mathrm{Al}_{2} \mathrm{O}_{3}$ ) for the SCR of NOx has been confirmed using both powder and washcoated honeycomb catalysts. Sulfate, phosphate and chloride anions help to stabilize the $\mathrm{Ag}(\mathrm{I})$ species on the $\mathrm{Al}_{2} \mathrm{O}_{3}$ support and promote its intrinsic activity of NOx reduction, although the apparent activity could be affected by the dispersion of precipitated $\mathrm{Ag}(\mathrm{I})$ species. $\mathrm{AgCl}$ was observed to have a much higher TOF for NOx reduction than silver oxide, $\mathrm{Ag}_{3} \mathrm{PO}_{4}$ or $\mathrm{Ag}_{2} \mathrm{SO}_{4}$. The SCR reaction mechanism over the $\mathrm{Al}_{2} \mathrm{O}_{3}$-supported silver compound catalysts is very similar to that over the $\mathrm{Ag} / \mathrm{Al}_{2} \mathrm{O}_{3}$ catalyst. Furthermore, the excellent performance of the monolith $\mathrm{AgCl} / \mathrm{Al}_{2} \mathrm{O}_{3}$ washcoated honeycomb catalyst for the SCR of NOx using ethanol as the reductant has been confirmed in bench tests using a heavy duty diesel engine. Therefore, we conclude that the silver precipitable compounds can be used to create and stabilize the active $\mathrm{Ag}(\mathrm{I})$ sites on $\mathrm{Ag}$ compound catalysts, and to facilitate the practical use of $\mathrm{Ag} / \mathrm{Al}_{2} \mathrm{O}_{3}$ in the SCR of NOx by hydrocarbons.

\section{Acknowledgements}

This work was financially supported by the Knowledge Innovation Program of the Chinese Academy of Sciences (KZCX1-YW-06-04), the National Science Foundation of China (20773158) and the Ministry of Science and Technology of China (2009AA064802, 2006AA06A304).

\section{References}

[1] T. Miyadera, K. Yoshida, Chem. Lett. 2 (1993) 1483-1486.

[2] T. Miyadera, Appl. Catal. B: Environ. 2 (1993) 199-205.

[3] M.C. Kung, K.A. Bethke, J. Yan, J.H. Lee, H.H. Kung, Appl. Surf. Sci. 121-122 (1997) 261-266.

[4] K.A. Bethke, H.H. Kung, J. Catal. 172 (1997) 93-102.

[5] S. Sumiya, H. He, A. Abe, N. Takezawa, K. Yoshida, J. Chem. Soc., Faraday Trans. 94 (1998) 2217-2219.

[6] S. Sumiya, M. Saito, H. He, Q.C. Feng, N. Takezawa, K. Yoshida, Catal. Lett. 50 (1998) 87-91.

[7] S. Kameoka, T. Chafik, Y. Ukisu, T. Miyadera, Catal. Lett. 55 (1998) 211-215.

[8] F.C. Meunier, J.P. Breen, V. Zuzaniuk, M. Olsson, J.R.H. Ross, J. Catal. 187 (1999) 493-505.

[9] K. Shimizu, J. Shibata, H. Yoshida, A. Satsuma, T. Hattori, Appl. Catal. B: Environ. 30 (2001) 151-162.

[10] T.E. Hoost, R.J. Kudla, K.M. Collins, M.S. Chattha, Appl. Catal. B: Environ. 13 (1997) 59-67.

[11] N. Aoyama, K. Yoshida, A. Abe, T. Miyadera, Catal. Lett. 43 (1997) 249-253.

[12] H.W. Jen, Catal. Today 42 (1998) 37-44.

[13] K. Takagi, T. Kobayashi, H. Ohkita, T. Mizushima, N. Kakuta, A. Abe, K. Yoshida, Catal. Today 45 (1998) 123-127.

[14] H. He, Y. Yu, Catal. Today 100 (2005) 37-47.

[15] H. He, X. Zhang, Q. Wu, C. Zhang, Y. Yu, Catal. Surv. Asia 12 (2008) 38-55.

[16] N. Bodganchikova, F.C. Meunier, M. Avalos-Borja, J.P. Breen, A. Pestryakov, Appl. Catal. B: Environ. 36 (2002) 287-297.

[17] A. Iglesias-Juez, A.B. Hungría, A. Martínez-Arias, A. Fuerte, M. Fernández-García, J.A. Anderson, J.C. Conesa, J. Soria, J. Catal. 217 (2003) 310-323.

[18] M.C. Kung, H.H. Kung, Top. Catal. 10 (2000) 21-26.

[19] R. Burch, J.P. Breen, F.C. Meunier, Appl. Catal. B: Environ. 39 (2002) 283-303.

[20] E. Seker, J. Cavataio, E. Gulari, P. Lorpongpaiboon, S. Osuwan, Appl. Catal. A: Gen. 183 (1999) 121-134

[21] A. Martínez-Arias, M. Fernández-García, A. Iglesias-Juez, J.A. Anderson, J.C. Conesa, J. Soria, Appl. Catal. B: Environ. 28 (2000) 29-41.

[22] X. She, M. Flyzani-Stephanopoulos, J. Catal. 237 (2006) 79-93.

[23] T. Miyadera, Appl. Catal. B: Environ. 13 (1997) 157-165.

[24] Y. Yu, H. He, Q. Feng, J. Phys. Chem. B 107 (2003) 13090-13092.

[25] Y. Yu, H. He, Q. Feng, H. Gao, X. Yang, Appl. Catal. B: Environ. 49 (2004) 159-171.

[26] Q.Y. Chang, H. He, Z.C. Ma, J. Inorg. Biochem. 102 (2008) 1736-1742.

[27] N. Aoyama, Y. Yamashita, A. Abe, N. Takezawa, K. Yoshida, Phys. Chem. Chem. Phys. 1 (1999) 3365-3367.

[28] R. Ke, Q. Chen, J. Li, Y. Zhu, J. Hao, Catal. Commun. 8 (2007) 589-592.

[29] A. Abe, N. Aoyama, S. Sumiya, N. Kakuta, K. Yoshida, Catal. Lett. 51 (1998) 5-9.

[30] B.Q. He, S.J. Shuai, J.X. Wang, H. He, Atmos. Environ. 37 (2003) 4965-4971.

[31] H.Y. Dong, S.J. Shuai, R.L. Li, J.X. Wang, X.Y. Shi, H. He, Chem. Eng. J. 135 (2008) 195-201.

[32] E.F. Iliopoulou, A.P. Evdou, A.A. Lemonidou, I.A. Vasalos, Appl. Catal. A: Gen. 274 (2004) 179-189.

[33] J.S. Hammond, S.W. Gaarenstroom, N. Winograd, Anal. Chem. 47 (1975) 21932199.

[34] L.H. Tjeng, M.B.J. Meinders, J. van Elp, J. Ghijsen, G.A. Sawatzky, R.L. Johnson, Phys. Rev. B 41 (1990) 3190-3199.

[35] B.V.R. Chowdari, R. Gopalkrishnan, K.L. Tan, Solid State Ionics 40 (1990) 709-713.

[36] C.D. Wagner, Discuss. Faraday Soc. 60 (1975) 291-300.

[37] V.K. Kaushik, Electron Spectrosc. Relat. Phemon. 56 (1991) 273-277.

[38] M. Romand, M. Roubin, J.P. Deloume, J. Solid State Chem. 25 (1978) 59-64

[39] Y.B. Yu, H.W. Gao, H. He, Catal. Today 93-95 (2004) 805-809.

[40] F.C. Meunier, V. Zuzaniuk, J.P. Breen, M. Olsson, J.R.H. Ross, Catal. Today 59 (2000) 287-304.

[41] S. Kameoka, Y. Ukisu, T. Miyadera, Phys. Chem. Chem. Phys. 2 (2000) 367-372.

[42] N. Bion, J. Saussey, M. Haneda, M. Daturi, J. Catal. 217 (2003) 47-58.

[43] K. Shimizu, J. Shibata, A. Satsuma, T. Hattori, Phys. Chem. Chem. Phys. 3 (2001) 880-884. 